\title{
Women Empowerment and Its Challenges in Jammu and Kashmir
}

\author{
Mohd Muzaffar Banday ${ }^{1 *}$, Dr. P. Ganesan ${ }^{2}$
}

\section{ABSTRACT}

In Jammu and Kashmir Woman are the most vulnerable section due to violence caused by militancy and armed conflict. They are facing number of challenges related to health, economy, education, politics, and more importantly they are traumatised due to prolonged depression of conflict in which number of women become widows. In this study researcher tried to access the freedom of movement within and outside their homes, freedom of acquiring education before and after their marriages and challenges faced by women were also identified with the help of primary and secondary data. Researcher found that women had high level of freedom for their education before marriage and they had high level of freedom for their movement both within and outside their villages.

Keywords: Women, Violence, Empowerment, Challenges

Jammu \& Kashmir is the disputed territory between Indian and Pakistan. Gender discrimination is on rise due to the prevailing social, economic and political turmoil's (Gul and Khan, 2013). Participation of women in the socioeconomic and political processes has taken a back seat, which has affected the process of development resultantly it has eroded their freedom of speech, freedom to get education and enhancement of employment opportunities. This situation has compelled them to be a silent spectator amidst the fast changing socioeconomic scenario. They have developed signs of exclusiveness resulting in an identity crisis. They are facing traumatized experiences with prolonged depression of conflict, making them mentally and emotionally sick. Women are the most vulnerable section of the society especially under situations of violence caused by militancy and armed conflict (Gul and Khan, 2013).

The Women is subjugated to violence in Kashmir from the past two decades due to conflict. A factor clearly responsible for inhibiting the choices of women in development is domestic violence (Dabla, 2009). Militancy and militarization has unleashed a wave of violence against women. The misuse of gun by pro- government and pro-freedom militants led to series of violent

\footnotetext{
${ }^{1}$ Ph.D Research Scholar, Department of Sociology, Annamilia University, Tamil Nadu, India

${ }^{2}$ Assistant Professor, Dept. of Sociology, Annamilia University, Tamil Nadu, India

*Responding Author

(C) 2016 M Banday, P Ganesan; licensee IJIP. This is an Open Access Research distributed under the terms of the Creative Commons Attribution License (http://creativecommons.org/licenses/by/2.0), which permits unrestricted use, distribution, and reproduction in any Medium, provided the original work is properly cited.
} 


\section{Women Empowerment and Its Challenges in Jammu and Kashmir}

acts against women, the state- sponsored gun in the hands of military and Para-military forces led to all sorts of excesses against women, including abusing their chastity. (Dabla, 2009) Violence against women is also present in the form of male control over women which has pushed women into the subordinate position. Even the educated and the economically independent women are at the receiving end, according to anecdotal evidence contained in police data (Sharma, 2010). The practice prevails in urban as well as rural areas of J\&K in all educational, economic, social, age, cultural and other groups and classes.

Thus empowerment as a solution, with the aim to improve the status of women in all the spheres of life, has been used in different ways such as the process of giving power, (Naryan, 2002) giving access to resource and decision making. It is said that this is the process of providing access to opportunities, which was denied in the past. Women empowerment refers to enhancing their position in the power structure of the society (Bhuyan, 2006) by giving them power to regulate their day-to-day lives in the social, political and economic domains which would enables them to move from the periphery to the centre stage.

\section{METHODOLOGY}

Kashmiri society is patriarchal in nature (Dabla, 2009), which has confined women within the boundaries of their homes. They had limited exposure to modern communication tools, and low level of education with limited freedom of interaction because of discrimination and violence. Under this backdrop researcher tried to access the women's freedom of education before and after marriage, freedom of movement and challenges faced by the women in the process of empowerment. For this purposes present study were carried out in Kupwara district of Jammu and Kashmir. With the help of purposive sampling 200 respondents 100 from each village namely Nutnusa and khooro of Handwara Thesil were selected. The data were collected by administering the set of questions through interview schedule related to their freedom of education and movement. Moreover secondary data were used to identify the challenge faced by the rural women in the process of empowerment. The collected primary data were analysed with the help of simple percentage method.

\section{ANALYSIS AND INTERPRETATION}

Socio economic background of the respondents

\begin{tabular}{|c|c|c|c|}
\hline Background & Sub group & N & Percentage \\
\hline \multirow{4}{*}{ Age } & 25 to 35 & 44 & 22 \\
\cline { 2 - 4 } & 36 to 45 & 52 & 26 \\
\cline { 2 - 4 } & 46 to 55 & 72 & 36 \\
\cline { 2 - 4 } & 56 to 65 & 22 & 11 \\
\cline { 2 - 4 } & Above 65 & 10 & 5 \\
\cline { 2 - 4 } & Total & 200 & 100 \\
\hline
\end{tabular}

(c) The International Journal of Indian Psychology, ISSN 2348-5396 (e)| ISSN: 2349-3429 (p) | 109 
Women Empowerment and Its Challenges in Jammu and Kashmir

\begin{tabular}{|c|c|c|c|}
\hline Background & Sub group & N & Percentage \\
\hline \multirow{4}{*}{ Marital status } & Married & 118 & 59 \\
\cline { 2 - 4 } & Widows & 30 & 15 \\
\cline { 2 - 4 } & Divorcees & 34 & 17 \\
\cline { 2 - 4 } & Separated & 18 & 9 \\
\cline { 2 - 4 } & Total & 200 & 100 \\
\hline \multirow{5}{*}{ Educational qualification } & Illiterate & 20 & 10 \\
\cline { 2 - 4 } & Primary & 34 & 17 \\
\cline { 2 - 4 } & SSLC & 50 & 25 \\
\cline { 2 - 4 } & HSC & 46 & 23 \\
\cline { 2 - 4 } & Degree professional & 8 & 4 \\
\cline { 2 - 4 } & Degree academic & 42 & 100 \\
\cline { 2 - 4 } & Total & 200 & \\
\hline
\end{tabular}

In this study researcher found, that out of total respondents, majority of them (36\%) belonged to the age group of 46-55 years, (22\%) of them belonged to 25-35 years , (26\%) belonged to 36-45 years of age, (11\%) belonged to 56-65 years of age and (5\%) of them belonged to above 65 years of age.

Also among the marital groups, majority (59\%) of the respondents are married, (15\%) are widows, (17\%) are divorced and (9\%) of respondents are separated. Separated women are those who are living apart from their husbands due to some reasons.

Considering the educational group, out of the total (10\%) of respondents are illiterates, $(17 \%)$ of them had acquired primary level education, (25\%) had acquired secondary school level education, (23\%) of them are higher secondary school level educated, it is interesting to note that researcher found only (4\%) of respondents with professional level of education, while as there are (21\%) of respondents who had acquired degree level education but in academic fields.

Opinion on freedom of movement

\begin{tabular}{|c|c|c|c|c|}
\hline S. No & Freedom of movement & Always & Some times & Never \\
\hline 1 & Friends & $107(53 \%)$ & $72(36 \%)$ & $21(10)$ \\
\hline 2 & Relatives & $121(60 \%)$ & $59(29 \%)$ & $20(10 \%)$ \\
\hline 3 & Marriage parties & $98(49 \%)$ & $88(44 \%)$ & $14(7 \%)$ \\
\hline 4 & Tourist places & $56(28 \%)$ & $50(25 \%)$ & $94(47 \%)$ \\
\hline 5 & Travel alone & $44(22 \%)$ & $70(35 \%)$ & $86(43 \%)$ \\
\hline 6 & Hospitals & $100(50 \%)$ & $66(33 \%)$ & $34(17 \%)$ \\
\hline 7 & Work places & $90(45 \%)$ & $76(38 \%)$ & $34(17 \%)$ \\
\hline
\end{tabular}

(c) The International Journal of Indian Psychology, ISSN 2348-5396 (e)| ISSN: 2349-3429 (p) | 110 


\section{Women Empowerment and Its Challenges in Jammu and Kashmir}

From the above table it is indicated that high level of freedom of movement were found in visiting friends (53\%), relatives (60\%) and marriage parties (49\%). one third of them are facing restrictions for travelling alone (22\%) and for visiting tourist places (28\%). They are free to visit hospitals (50\%) and wok place (90\%).

\section{Distribution of respondents on their opinion about Access to education}

\begin{tabular}{|c|c|c|c|c|}
\hline S. No & Access & Agree & Neutral & Disagree \\
\hline 1 & Access to education before marriage & $100(50 \%)$ & $36(18 \%)$ & $64(32 \%)$ \\
\hline 2 & Access to education after marriage & $78(39 \%)$ & $36(18 \%)$ & $86(43 \%)$ \\
\hline 4 & Freedom for professional education & $90(45 \%)$ & $40(20 \%)$ & $70(35 \%)$ \\
\hline 5 & Freedom of children education & $187(94 \%)$ & $8(4 \%)$ & $5(2 \%)$ \\
\hline
\end{tabular}

From the given results, it is observed that women had high level of access to education before marriage (50\%) and after their marriage considerable number (43\%) of them had low level of access to education. Moreover nearly half of them (45\%) had freedom of receiving professional education. Further almost all of them have accepted that they are free to educate their children (94\%).

\section{Challenges to Empowerment of Women in Jammu and Kashmir}

The State government has made tangible efforts to empower women by helping women to help themselves and their families by providing them number of programmes such as Support to training and employment programme, Empower skilled women programme, Development of Vocational Skills, MGNREGA and National mission for empowerment of women, but with a huge unemployed women population and significant number of widows and half-widows these programmes are not sufficient and these programmes lack the spirit of brining change in the attitude of patriarchy. There are many challenges which the women of Jammu and Kashmir is facing significant among them is violence, which is perpetuated at domestic level as well as at state level and illiteracy and ignorance of rural women constraint their empowerment process. Research findings across the state have found that girls are getting married at an early age which affects their overall development to a greater extent. Lack of decision making authority has further pushed women into the subordinate position. Many customs and cultural practices like parents do not send their daughters to schools when they attain puberty, lack of political participation, lack of awareness, Inadequate and unorganized health care delivery system and unemployment are the major obstacles in the path of women empowerment.

\section{FINDINGS AND CONCLUSION}

Majority of the respondents had freedom of movement for visiting friends, relatives, hospitals and marriage parties but they are facing considerable level of restriction for travelling alone outside their villages and districts. Most of the respondents had high level of access to education before marriage and after marriage as a customary practise they are stopping their education. 


\section{Women Empowerment and Its Challenges in Jammu and Kashmir}

Further women in the study area are affected due to violence, conflict and unemployment which have made women selves of their males. Despite number of programmes and policies for their upliftment, women in kashmiri are facing number of challenges related to their health, economy, education, politics, such as domestic violence, declining sex ratio, female feticide and infanticide, late marriage, state violence, dowry harassment, eve teasing, unequal wages, child sexual abuse, child labour and sexual harassment at work. Thus empowerment of women in Jammu and Kashmir demands sustained efforts like improving their education and awareness, involving them into developmental process and promoting welfare atmosphere for women.

\section{Acknowledgments}

The author appreciates all those who participated in the study and helped to facilitate the research process.

\section{Conflict of Interests}

The author declared no conflict of interests.

\section{REFERENCE}

Bhuyan, Dasarathi. (2006). "Empowerment of Indian women: A challenge of 21st century." Orissa Review, 1 : 60-63.

Dabla, Bashir Ahmed (2009), Domestic violence against women in the Kashmir valley. sage publication.

Gul, Showkeen Bilal Ahmad, and Zebun Nisa Khan (2014). "Assessment and Understanding of Gender Equity in Education in Jammu and Kashmir." MD Publications 1.6: 1-12.

Narayan-Parker, Deepa, (2002.) ed. Empowerment and poverty reduction: A sourcebook. World Bank Publications.

Sharma, Pallavi (2010). "Violence against women on the rise in Jammu and Kashmir." Hindustan Times 7 (2010).

How to cite this article: M Banday, P Ganesan (2016), Women Empowerment and Its Challenges in Jammu and Kashmir, International Journal of Indian Psychology, Volume 3, Issue 4, No. 75, ISSN:2348-5396 (e), ISSN:2349-3429 (p), DIP:18.01.048/20160304, ISBN:978-1365-50727-4 